\title{
Editorial
}

\section{O conceito de Bem Viver e a nova agenda bioética do Século 21}

O conceito de Felicidade Nacional Bruta adotado desde os anos 1970 no Butão, pequeno reino encravado na cordilheira do Himalaia, entre a China e Índia, define que o princípio básico para garantir a felicidade é que a economia esteja a serviço do bem-estar da população. Isso é bem diferente do que se viu na recente crise econômica mundial, quando inimagináveis quantias de dinheiro público - suficiente para acabar com a pobreza e a exclusão social no mundo periférico - foram aplicadas pelos países capitalistas centrais para evitar a quebra de grandes empresas privadas, em nome da manutenção da produção, da virtual garantia de empregos e da sobrevivência do sistema. Como tudo isso tem a ver diretamente com a qualidade de vida e a sobrevivência das pessoas, parece ser apropriado que a Bioética, nos próximos anos, comece a aprofundar debates que incorporem as relações entre bioética e política proposta pela "Bioética de Intervenção", e o conceito de Biopolítica desenvolvido por Michel Foucault.

Uma contribuição interessante originada na América Latina e que traz novidades no debate contemporâneo sobre "desenvolvimento" é o conceito de Bem Viver, antiga filosofia de vida das sociedades indígenas da região andina, especialmente da Bolívia, que já a incluiu na sua Constituição. Nesse conceito não contam tanto as riquezas, ou seja, as coisas que as pessoas produzem, mas o que as coisas produzidas proporcionam concretamente para a vida das pessoas. Na formulação da Filosofia do Bem Viver não são levados em consideração apenas os bens materiais, mas outros referenciais como o conhecimento, o reconhecimento social e cultural, os códigos éticos e espirituais de conduta, a relação com a natureza, os valores humanos, a visão de futuro...

De acordo com esse contexto, a economia deve se pautar por uma convivência solidária, sem miséria, sem discriminações, garantindo um mínimo de coisas necessárias para a sobrevivência digna de todos. O Bem Viver expressa a afirmação de direitos e garantias sociais, econômicas e ambientais. Todas as pessoas têm igualmente o direito 
a uma vida decente que lhes assegure saúde, alimentação, água limpa, oxigênio puro, moradia adequada, saneamento ambiental, educação, trabalho, emprego, descanso e ócio, cultura física, vestuário, aposentadoria, etc.

Todas estas idéias têm relação direta com a Bioética que vários grupos de estudo e pesquisa latino-americanos comprometidos com a realidade sócio-cultural dos seus países haviam começado a produzir na região já nos anos 1990. Tal processo original de caminhada acadêmica e construção científica se revelou acertado quando, em outubro de 2005, com o apoio unânime de 191 nações e a participação decisiva dos países da América Latina, a Organização das Nações Unidas para a Educação, a Ciência e a Cultura - UNESCO - homologou a Declaração Universal sobre Bioética e Direitos Humanos. O referido documento - o mais importante já produzido mundialmente sobre Bioética - politizou definitivamente a agenda internacional deste "novo território do saber" (no dizer de Francesco Bellino), incorporando à sua pauta praticamente todas as questões relacionadas com o contexto de Bem Viver.

Em novembro de 2009 a UNESCO promoveu na Cidade do México a $16^{\text {a }}$. Sessão do International Bioethics Committee - organismo composto por membros de 36 países e que tem a mais expressiva representatividade e legitimidade mundial da área de Bioética. A referida reunião reconheceu formalmente a paternidade da América Latina com relação à inclusão - na Declaração Universal de Bioética acima referida - das questões sanitárias, sociais e ambientais na nova agenda bioética do Século 21.

\section{Volnei Garrafa}

Editor Chefe - RBB 